\title{
Joint hypermobility-asset or liability? A study of joint mobility in ballet dancers
}

\author{
R. GRAHAME AND J. M. JENKINS \\ Department of Rheumatology, Guy's Hospital, London
}

Much interest has been focused on generalized joint hypermobility in recent years with particular reference to its possible adverse sequelae. Though a feature of many hereditary disorders of connective tissue (listed in Table I), generalized joint laxity may occur apparently in the absence of other abnormalities and probably represents the upper end of a spectrum of the range of normal joint mobility. Lack of precise criteria has hindered attempts to ascertain the incidence of joint hypermobility in a normal population. The term 'hypermobility syndrome' was devised by Kirk, Ansell, and Bywaters (1967) to describe this entity when it is the cause of musculoskeletal complaints.

Table I Hereditary disorders of connective tissue manifesting generalized joint hypermobility

\begin{tabular}{|c|c|c|}
\hline Disorder & Author & Date \\
\hline Marfan's syndrome & Marfan & 1896 \\
\hline $\begin{array}{l}\text { Achard's syndrome (arach- } \\
\text { nodactyly with mandibular- } \\
\text { facial dysostosis) }\end{array}$ & Parish & 1960 \\
\hline $\begin{array}{l}\text { Marfanoid hypermobility } \\
\text { syndrome }\end{array}$ & $\begin{array}{l}\text { Walker, Beighton, } \\
\text { and Murdoch }\end{array}$ & 1969 \\
\hline Ehlers-Danlos syndrome & Tschernogubow & 1892 \\
\hline Osteogenesis imperfecta & McKusick & 1966 \\
\hline Homocystinuria & $\begin{array}{l}\text { Schimke, } \\
\text { McKusick, Huang, } \\
\text { and Pollack }\end{array}$ & 1965 \\
\hline Hyperlysinaemia & $\begin{array}{l}\text { Ghandimi, } \\
\text { Binnington, and } \\
\text { Pecora }\end{array}$ & 1965 \\
\hline
\end{tabular}

There seems little doubt that generalized hypermobility predisposes to a number of sequelae irrespective of aetiology, e.g.:

(i) Injury to ligaments (Nicholas, 1970).

(ii) Recurrent dislocation, e.g. of the patella (Carter and Sweetnam, 1958); congenital dislocation of the hip (Carter and Wilkinson, 1964); and of various joints in the Ehlers-Danlos syndrome (Beighton and Horan, 1969).

(iii) Recurrent knee and ankle effusions (Sutro, 1947).

(iv) Premature osteoarthrosis. This is largely based on uncontrolled observation but the clinical impression is a strong one.

There are few data on the possible benefits that may accrue from the possession of hypermobile joints. The purpose of the present investigation is to determine whether generalized hypermobility confers a positive advantage in the selection for training of would-be ballet dancers. Flexibility of the spine, hips, and ankles is, of course, the hall-mark of the ballet dancer and the presence of hypermobility of these joints would be attributable to training. The presence in the dancers of joint laxity in those other joints whose range of movement is not the object of training would indicate a tendency to generalized joint hypermobility. A preliminary account of this work has been published elsewhere (Grahame, 1971).

\section{Method}

53 students from the Royal Ballet School in London were examined according to the following criteria (modified from Beighton and Horan, 1969), by testing their ability to perform the following manoeuvres:

(1) Passive dorsiflexion of the fifth metacarpophalangeal joint to $90^{\circ}$.

(2) Passive opposition of the thumb to the flexor aspect of the forearm.

(3) Passive hyperextension of the elbow beyond $10^{\circ}$.

(4) Passive hyperextension of the knee beyond $10^{\circ}$.

(5) Passive dorsiflexion of the ankle to beyond $15^{\circ}$ past the right-angle.

(6) Forward flexion with hands flat on floor (knees fully extended).

A quantitative test of both fifth metacarpophalangeal joints was also performed (Fig. 1). A predetermined force (2 lb.) was delivered to the flexor aspect of the little finger 
at the exact level of the skin crease, overlying the distal interphalangeal joint with palm firmly pressed on the edge of a table. A push-pull gauge (John Chatillon and Son, Inc.) was used for this purpose. The resulting angle of passive dorsiflexion of the little finger was measured by a suitably placed protractor and recorded as less than $30^{\circ}$, $30-60^{\circ}, 60^{\circ}-90^{\circ}$, or more than $90^{\circ}$.

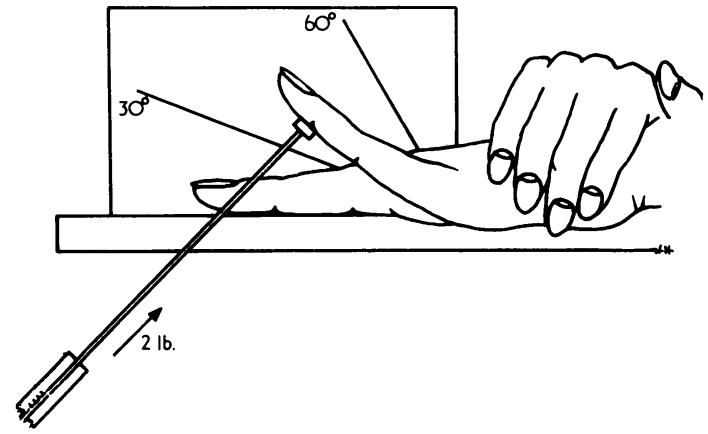

FIG. 1 Quantitative method of measuring mobility of the metacarpophalangeal joint (see text).

The reproducibility of this method was assessed by one of us (R.G.) as follows:

Both the little fingers of six volunteers were tested in random order in such a way that the identity of the owner remained unknown to the observer. The six results were identical in eleven of the twelve fingers tested and in five out of six in the twelfth.

The distance between the skin creases overlying the distal interphalangeal and the metacarpophalangeal joints was measured to the nearest millimetre by a ruler and these were also recorded.

The same procedures were carried out on a group of student nurses from the Preliminary Training School of the Guy's Hospital School of Nursing who kindly volunteered to act as controls. Details, inciuding age, height, weight, and body proportion, of the ballet students and student nurses are given in Table II. All subjects were caucasian females.

Table II Particulars of subjects studied

\begin{tabular}{|c|c|c|c|}
\hline \multirow{2}{*}{$\begin{array}{l}\text { Group of subjects } \\
\text { Number }\end{array}$} & \multirow{2}{*}{$\begin{array}{l}\begin{array}{l}\text { Ballet } \\
\text { students }\end{array} \\
53\end{array}$} & \multirow{2}{*}{\multicolumn{2}{|c|}{$\begin{array}{l}\begin{array}{l}\text { Student } \\
\text { nurses }\end{array} \\
53\end{array}$}} \\
\hline & & & \\
\hline Mean age $( \pm \mathrm{SD})(\mathrm{yrs})$ & $17 \cdot 5( \pm 1 \cdot 0)$ & $18 \cdot 5$ & $( \pm 0.4)$ \\
\hline Mean height $( \pm \mathrm{SD})$ & $5^{\prime} 4^{\prime \prime}\left( \pm 1 \cdot 5^{\prime \prime}\right)$ & $5^{\prime} 5^{\prime \prime}$ & $\left( \pm 2 \cdot 3^{\prime \prime}\right)$ \\
\hline Mean weight (lb.) $( \pm$ SD) & $107( \pm 7 \cdot 8)$ & $128 \cdot 8$ & $( \pm 12 \cdot 1)$ \\
\hline $\begin{array}{l}\text { No. in whom arm span } \\
\text { exceeded height }\end{array}$ & 43 & 7 & \\
\hline $\begin{array}{l}\text { Mean upper segment/ } \\
\text { lower segment ratio } \\
( \pm \text { SD) }\end{array}$ & $0.92( \pm 0.05)$ & ND & \\
\hline
\end{tabular}

$\mathrm{ND}=$ not done

In both groups all subjects were questioned concerning personal and family history oï joint disorders.

\section{Results}

The results of the quantitative tests are shown in Fig. 2. In respect of all the manoeuvres tested (with $\frac{\square}{\omega}$ the exception of passive dorsiflexion of the little finger), there was a significantly higher incidence of hypermobility in the ballet students than in the nurses.

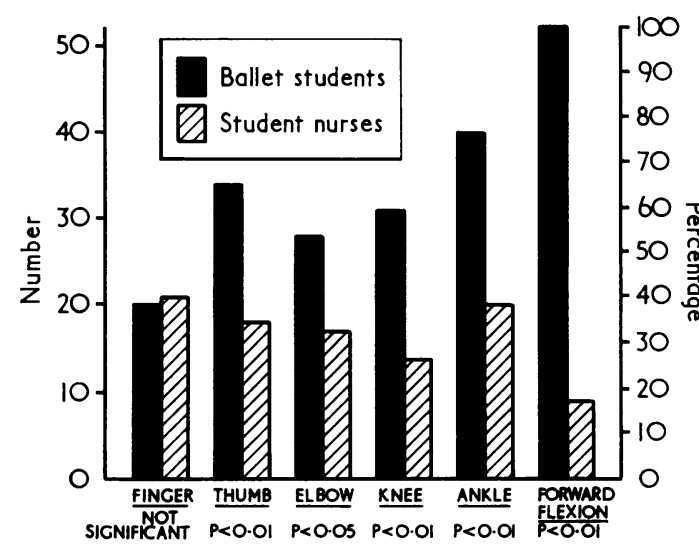

FIG. 2 Incidence of hypermobility in individual joints tested in 53 ballet students and 53 student nurses (see text).

In the quantitative test of passive dorsiflexion of the little finger using a fixed force, there was a significan $(P<0.01)$ difference in that the angle of deflectio was greater among the dancers (Table III). This could be explained either by an increased ligamentous laxity on the part of the dancers or by a greater finger length on the part of the nurses (since the moment about a force is the product of the force and the distance from the fulcrum that force is applied). However the mean distance between the relevant skin creases for the dancers and nurses were 4.40 and 4.55 $\mathrm{cm}$. respectively, so that the disparity cannot be explained on the basis of differences in finger length.

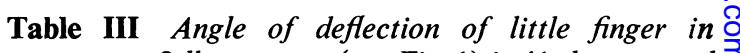
response to $2 \mathrm{lb}$. pressure (see Fig. 1) in 41 dancers and 52 nurses (per cent.)

\begin{tabular}{|c|c|c|c|c|}
\hline Angle & $<30^{\circ}$ & $30-60^{\circ}$ & $60-90^{\circ}$ & $>90^{\circ}$ \\
\hline $\begin{array}{l}41 \text { Ballet students } \\
\text { (per cent.) }\end{array}$ & 0 & 37 & 61 & 2 \\
\hline $\begin{array}{l}52 \text { Student nurses } \\
\text { (per cent.) }\end{array}$ & 0 & 61 & 37 & 2 \\
\hline
\end{tabular}

13 per cent. of the dancers but none of the nurses $\stackrel{0}{\odot}$ knew of a first-degree relative who suffered from $\stackrel{\infty}{\rightarrow}$ recurrent knee effusions. Apart from this there was no significant difference in respect of joint disease in the immediate family.

Although the arm span was in excess of the height $\frac{O}{10}$ in 43 (81 per cent.) of the ballet students compared to 
only seven (13 per cent) of the nurses, this is unlikely to be due to a 'Marfanoid' tendency, since the observed distribution of the upper segment/lower segment ratio in this group was identical with that predicted from published data on normal white females of the same age (McKusick, 1966).

\section{Discussion}

Ballet dancers are endowed with a generous range of movement of the spine, hips, and ankles which is a key factor in the performance of their art and is the result of deliberate painstaking training extending over many years and often commencing in childhood. However, hyperextension of the knees, elbows, and fingers leads to unaesthetic postures and is carefully avoided by dancers through appropriate muscular control. Since training is not directed to hyperextending these joints, the presence of hypermobility in them is likely to have been hereditary rather than acquired. This study demonstrates that, compared with a control group of nurses, ballet students do show generalized joint hypermobility, and that this may have favoured their selection for training.

Strength is added to the hereditary theory by the greater incidence of knee effusion (a known complication of hypermobility) among the first-degree relatives of the dancers than among those of the controls.

Further study is required to determine better methods of measuring joint mobility. This will enable comprehensive epidemiological studies of joint hypermobility to be performed, so that the true incidence of generalized joint hypermobility may be ascertained and its natural history plotted.

\section{Summary}

A controlled study of joint mobility in 53 ballet students has shown that they possess a significantly greater incidence of joint hypermobility even in those joints not the object of training. It is suggested that this may have been one of the factors favouring their selection for training. Generalized joint hypermobility may thus confer positive advantages as well as its known adverse sequelae.

A new method is described for quantitating extensibility of the fifth metacarpophalangeal joint.

We would like to thank the Principal of the Royal Ballet School, the Matron of Guy's Hospital, and all those who took part in the comparative study; also Mr. Ivor Robertson, F.R.C.S., for helpful advice.

\section{References}

Beighton, P., AND Horan, F. (1969) J. Bone Jt Surg., 51B, 444 (Orthopaedic aspects of the Ehlers-Danlos syndrome)

CARTER, C., AND SweEtnam, R. (1958) Ibid., 40B, 664 (Recurrent dislocation of the patella and the shoulder. Their association with familial joint laxity)

- AND WILKINSON, J. (1964) Ibid., 46B, 40 (Persistent joint laxity and congenital dislocation of the hip)

Ghadimi, H., Binnington, V. I., AND Pecora, P. (1965) New Engl. J. Med., 273, 723 (Hyperlysinaemia associated with retardation)

Grahame, R. (1971) Proc. roy. Soc. Med. 64, 692 (Joint hypermobility. Clinical aspects)

KIrk, J. A., Ansell, B. M., AND Bywaters, E. G. L. (1967) Ann. rheum. Dis., 26, 419 (The hypermobility syndrome)

Marfan, A. B. (1896) Bull. Mém. Soc. méd. Hôp. Paris, $3^{\bullet}$ sér. 13, 220 (Un cas de déformation congénitale des quatre membres, plus prononcée aux extrémités, charactérisée par l'allongement des os avec un certain degré d'amincissement)

McKusick, V. A. (1966) 'Heritable Diseases of Connective Tissue'. Mosby, St. Louis

Nicholas, J. A. (1970) J. Amer. med. Ass., 212, 2236 (Injuries to knee ligaments)

Parish, J. G. (1960) Proc. roy. Soc. Med., 53, 515 (Skeletal syndromes associated with arachnodactyly)

Schimke, R. N., McKusick, V. A., Huang, T., and Pollack, A. D. (1965) J. Amer. med. Ass., 193, 711 (Homocystinuria)

SuTRO, C. J. (1947) Surgery, 21, 67 (Hypermobility of knees due to overlengthened capsular and ligamentous tissues)

TSCHERNOGUBOW, A. (1892) Mh. prakt. Derm., 14, 76 (Cutis laxa)

Walker, B. A., Beighton, P. H., AND Murdoch, J. L. (1969) Ann. intern. Med., 71, 349 (The Marfanoid hypermobility syndrome) 